\author{
G.T. Yedgina ${ }^{1}$, R.M. Zhumashev ${ }^{1}$, Khaled Abou Taam ${ }^{2}$, L.I. Zuyeva ${ }^{1}$ \\ ${ }^{1}$ Ye.A.Buketov Karaganda State University, Kazakhstan; \\ ${ }^{2}$ Lebanese University, Lebanon \\ (E-mail: vastfak1999@mail.ru)
}

\title{
N.A. Nazarbayev, second secretary of the regional committee of the Communist Party of Kazakhstan
}

\begin{abstract}
In December 1977 at the VIII plenum of the Karaganda regional committee of the Communist Party of Kazakhstan N.A. Nazarbayev was elected second secretary of the regional committee of the Communist Party of Kazakhstan. In a new position N.A. Nazarbayev faced the same challenges as he had before, but on a much larger scale. Analysis of the report of the second secretary of the regional committee of the Communist Party of Kazakhstan N.A. Nazarbayev allowed the authors to conclude that in the period 1977-1979 N.A. Nazarbayev demonstrated all the great opportunities and hidden potential in managing people and the ability to solve vital issues, significantly strengthened the regional committee of the party, considerably expanded his sphere of influence. His energy, knowledge, experience, business qualities and great abilities began to manifest even brighter.
\end{abstract}

Keywords: Republic of Kazakhstan, First President, history, secretary, labor activity, Communist party, Kazakhstan, Karaganda region.

N.A. Nazarbayev, the first President of the Republic of Kazakhstan, is a world-class politician whose labor and political activities began in the Karaganda region, in the city of Temirtau in 1960. Here, he studied and gained experience. Having passed the labor path from the general laborer of the Domenstroy construction department of the Kazmetallurgstroy trust, the cast-iron machine worker for casting machines, the furnaceman, the gasman of the blast furnace shop to the secretary of the party committee of the Karaganda Metallurgical Plant in Temirtau, N.A. Nazarbayev was transferred to the city of Karaganda in connection with his appointment to the post of the secretary of the Communist Party of Kazakhstan in March 1977, and then to that of the second secretary of the Communist Party of Kazakhstan in December 1977.

Industrial Karaganda newspaper dated December 28, 1977 contained «Information message on the plenum of the regional committee of the Communist Party of Kazakhstan» [1], which reported on the appointment of N.A. Nazarbayev as the second secretary of the Communist Party of Kazakhstan regional committee: The VIII plenum of the Karaganda regional committee of the Communist Party of Kazakhstan was held the previous day.

Secretaries of city and district party committees, chairmen of executive committees of city and district Councils of People's Deputies, chairmen of regional trade union committees, heads and secretaries of party organizations of enterprises, construction sites, state farms, chairmen of city and district people's control committees, secretaries of city and district committee of the Komsomol, scientists, culture, print, television and radio workers were invited at the plenum.

V.K. Akulintsev, member of the Central Committee of the CPSU, first secretary of the Karaganda regional committee of the Communist Party of Kazakhstan made a report «On the Results of the December (1977) Plenary Session of the CPSU Central Committee and the tasks of the regional party organization, arising from the speech of Comrade L.I. Brezhnev, General Secretary of the CPSU Central Committee, Chairman of the Presidium, Supreme Soviet of the USSR at the Plenum of the Central Committee.

The first secretary of the Karaganda city party committee M.M. Ustinovsky, the first secretary of the Temirtau city party committee A.M. Anokhin, the first secretary of the Telman district party committee P.M. Ishchenko, the general director of the Karaganda ugol association V.F. Liannoy, the machine operator of the Industrial farm of the Nurinsky district A.Ye. Bodnar, the director of the Karaganda metallurgical plant 0. I. Tishchenko, the First Secretary of the Abay city party committee I.I. Bedash, the team leader of the integrated brigade of the Mikhailovskaya mine, the Hero of Socialist Labor, deputy of the Supreme USSR Council Ya.M. Musagaliyev, the Head of Glavcentrostroy, I.Ye. Grunskoy, the First Secretary of the Ulyanovsk District Party Committee, A.S. Bosenok, the Chairman of the Executive Committee of the Saransk City Council of People's Deputies M.A. Lebedenko participated in the debate on the report. 
The Plenum of the Regional Committee of the Communist Party of Kazakhstan unanimously approved the decisions of the December (1977) Plenary Session of the Central Committee of the CPSU, the provisions and conclusions contained in a bright, programmatic speech by the General Secretary of the Central Committee of the CPSU, Chairman of the Presidium of the Supreme Council of the USSR Comrade L.I. Brezhnev at the Plenum of the Central Committee, and adopted relevant decision on the issue under discussion.

The plenum relieved A.S. Spanov of the duties of the second secretary and member of the bureau of the regional committee of the Communist Party of Kazakhstan in connection with the transfer to another position.

The plenum elected N.A. Nazarbayev as the second secretary of the regional committee of the Communist Party of Kazakhstan.

The plenum elected V.G. Anufriyev as the secretary and members of the bureau of the regional committee of the Communist Party of Kazakhstan.

The second secretary of the Central Committee of the Communist Party of Kazakhstan A.G. Korkin, took part in the plenary session.

The inspector of the Central Committee of the Communist Party of Kazakhstan V.I. Betekhtin took part in the plenary session [1].

In a new position N.A. Nazarbayev faced the same challenges as he had before, but on a much larger scale.

On January 10, Karaganda held a meeting of workers' representatives of the region with the participation of party, Soviet, and trade union workers, Komsomol bodies, those of national control, culture, press, television and radio, which discussed and accepted the socialist obligations of the working people of the region for 1978, at which the second secretary of the regional committee of the Communist Party of Kazakhstan N.A. Nazarbayev made a report. By studying the text of the report, we can get acquainted with the nature of N.A. Nazarbayev's activity in his new post. The text of this report was published in Industrial Karaganda newspaper on January 12, 1978 in the article «Putting All Reserves Into Action» [2]: the speaker said that in the memory of the Soviet people and all progressive humanity 1977 would forever remain as the year of the 60th anniversary of the Great October Revolution and the adoption of the new Soviet Constitution. Those great significant events had caused an unprecedented scale of socialist competition. Actively participating in it, the workers of the region persistently had solved the problem of further growth in the volume of production and its implementation, increasing the efficiency and quality of all work [2].

N.A. Nazarbayev started with the results achieved and stated that since the beginning of the five-year period, the volume of industrial production in the country had increased by 7.4 percent. In addition to the plan, products worth 30 million rubles had been sold. 1.650 thousand tons of coal and 560 million $\mathrm{kW}$ hours of electricity had been produced, a lot of open-hearth steel, chemical products and coal engineering for 7 million rubles of consumer goods had been manufactured. More than 1 billion rubles of capital investments had been mastered, a number of large capacities of the heavy industry, as well as light and food industry facilities, agriculture, transport, communications, and a million square meters of housing had been put into operation.

Agricultural workers had completed two years' tasks in the production and procurement of vegetables, potatoes, meat, milk, eggs, and wool. Transport and communications enterprises, organization of domestic and public services and trade had coped with their obligations. Since the beginning of the tenth five-year period, public education, health care, and culture had been further developed. That had been facilitated by high labor enthusiasm and creative activity of the masses.

Many valuable patriotic initiatives and undertakings had appeared at the enterprises and organizations of the region in response to the party's call to mark the anniversary of the October Revolution by striking labor. Following the example of the Zapadnaya mine team, whose initiative had been approved by the Central Committee of the Communist Party of Kazakhstan, competition had begun for fulfilling the plans for the first two years of the five-year plan for the 60th anniversary of the Great October Revolution. By that time, the initiator mine had been named after the 60th anniversary of the October Revolution.

The collectives of the Mikhailovskaya mine (with the highest productivity for a mining worker, 138 tons per month), as well as the Lenin, Dolinskaya, Severnaya, and Kostenko ones had shown the samples of creative work. Noteworthy was the experience of the Gorbachev mine, which worked without lagging sites and brigades throughout the ninth five-year period and the first and second years of the tenth one.

The participants of the «agreement of fifteen», the teams of fifteen mining sites who had pledged to produce five hundred or more thousand tons of coal per year of the same lava, deserved mentioning, along with the parties of the «agreement of nine», the tunneling teams who had agreed to pass no less than 40005000 linear meters of mine workings for a year. 
The following sites had fulfilled their high obligations ahead of schedule: the site led by L.N. Povalyaev from the mine named after the 50th anniversary of the October Revolution, V.D. Te from the mine named after the 60th anniversary of the October Revolution, A.K. Romanyuta from the Severnaya mine, tunneling brigades of V N. Zavedeyev from the Molodezhnaya mine, Hero of Socialist Labor A.A. Kubaychuk from the Maykudukskaya mine, M.P. Kurnikov from the Severnaya mine, and R.E. Litman from the mine named after Lenin.

The miner and foreman of the integrated brigade of the Molodezhnaya mine V.P. Babich, the driver of mining excavation machines of the Kostenko mine A. Zhanaydarov, the head of section No. 1 of the Severnaya mine A.K. Romanyuta, geologists L.F. Dumler, the head of the Central Kazakhstan Territorial Geological Administration, and V.I. Shibrik, the head of the detachment of the thematic party of the TSU CC had become the winners of the 1977 State Prize for outstanding achievements in work.

S.V. Drozhzhin's team of rollersmen of sheet rolling shop No. 2, the initiator of the regional competition, was working very well at the Karaganda Metallurgical Combine under the slogan «Qualified personnel — for the five years of efficiency and quality». The initiative had been supported by the plant's 370 teams, shifts, workshops and industries (ten thousand people). On the account of S.V. Drozhzhin's team there were almost 10 thousand tons of superplanned metal with annual obligations of 5250.

The brigade of the steelworker of the open-hearth furnace shop No. 1, the delegate of the 16th Congress of Trade Unions of the USSR A. Zh. Zhunusov constantly overlaped the indicators planned. The brigade had increased steel production on orders to 99.3 percent with an obligation of 97.3 percent.

The teams of the Karagandashakhtoprohodka management and management No. 1 of the Kazstalkonstruktsiya trust had fulfilled the plan for two years of the five-year plan ahead of schedule.

I.P. Gress' brigade of the MMC-1009 of the Karagandaselstroy-10 trust, the initiator of the competition among builders, had successfully fulfilled its obligations, monthly exceeding the volume of work by ten to fifteen percent.

The staff of the Karaganda Order of the Red Banner of Labor of the heating equipment plant named after the 50th anniversary of the USSR, in addition to the annual plan, sold 1.937 thousand rubles of products, with an obligation of 1 million rubles.

Karaganda Odezhda had sold products for more than 1.5 million rubles over the plan in a year. Labor productivity has increased by 6 percent compared to last year. The proportion of products with the Quality Mark has been brought up to 19 with an obligation of 17 percent.

Collectives of the shoe factory and the hosiery factory named after the 60th anniversary of the October Revolution had also overtaken the commitments made.

Great success had been achieved by the team leader of drivers of heavy trucks A.I. Denk, who on September 7 had completed his personal five-year plan. The driver of a heavy-weight road train from a convoy No. 2576, laureate of the State Prize of the Kazakh SSR N.P. Mirchev had managed the five-year plan on October 17.

Obligations of the sale of livestock products to the state for two years had been fulfilled ahead of schedule by the state by the following farms: Proletarsk, Chernigov, Karaganda and Leninsk farms, as well as 5 poultry farms and, in general, an association for egg poultry farming.

The initiator of the regional competition, milkmaid of the Toparsky state farm of the Michurinsky district Ye. A. Polyamskaya, N. Ye. Pomerantseva from the same state farm, N.I. Vorobyeva from the Karaganda state farm, Hero of Socialist Labor N.P. Dulina, shepherd of the Arkalyksky state farm, Hero of Socialist Labor S. Blyalov, shepherd of the Dogalansky state farm A. Nestipkhanov and many others had successfully coped with their obligations.

In total, by November 7, collectives of 60 enterprises, 750 workshops, sections, brigades, more than thirty thousand workers had coped with the plans of two years of the five-year plan [2].

Then N.A. Nazarbayev turned to negative resultsand stated that a number of collectives had not kept their word in the anniversary year. The cities of Abay, Saran, Temirtau had failed their obligations. The Karaganda Cement Plant, the furniture association, and the Abay City Industrial Plant had committed a great debt in sales and production.

Last year hundreds of thousands of tons of cast iron, steel, rolled metal, a lot of calcium carbide, cement, lumber and synthetic products had been lost to the national economy.

The industry of the region had not implemented a plan for the growth of labor productivity. Every fourth enterprise had failed with the indicator. For this reason, almost 30 million rubles of products had been undersold. 
In the region, there was an increase in the price cost of production; overspending had amounted to almost 13 million rubles.

Every third enterprise had not fulfilled the plans to reduce the cost of production.

The Karagandagormash association had worked unsatisfactorily. For the year it undersold products for more than 900 thousand rubles. The valuable initiative of the brigade of S. Ye. Alimkin on the introduction of an industrial contract had not found proper support in that association.

Miners had worked below their capabilities. Eight mines had not coped with the annual coal production plan. The miners of the Kazakhstanskaya (named after the 50th anniversary of the USSR), Aktasskaya and Karagandinskaya mines had a particularly big debt. In general, the Association had not fulfilled the annual plan for the growth of labor productivity. 17 mines had that figure below the set. Mining plan had not been implemented. The debt was almost 25 kilometers.

Metallurgists had broke their commitments. Chemists of the SR plant, who had been in the forefront for many years in a row, had lagged behind the plan.

The reasons for the unsatisfactory work of industrial enterprises were shortcomings in the organization of labor and production, violation of job descriptions and technological discipline, large excess downtime, accidents, and staff turnover. In just six months, the total loss of working time had amounted to 78.8 thousand man-days, including 22 thousand man-days for absenteeism.

Serious shortcomings existed in capital construction. Almost 174 million rubles of fixed assets had not been put into the plan the previous year. The implementation of the capital investment development plan had been 88 percent. A housing plan had been disrupted. Not a single Glavcentrostroy trust had managed the contracting program; trusts of Karagandaselstroy-10, Karagandavodstroy and others had also failed the contracting programs. 68 of the 157 primary contracting departments had not completed the contracting program; they had undeveloped nearly 50 million rubles.

In construction, labor productivity was low. That indicator was not fulfilled by every second construction organization. Over the first half of the year, the total loss of working time had amounted to 61 thousand mandays, 16 thousand working days had been lost from day-time downtimes, 21 thousand working days had been lost from absenteeism and 30 thousand man-days had been lost from absences with permission of the administration.

The proportion of products with the state quality mark was extremely small. In the total volume it was 5.5 percent; 24 percent of products subject to certification had not been certified.

An insignificant proportion of products with the Quality Mark in the iron and steel industry ( 0.4 percent); Karaganda ugol association, Karagailinsky mining and processing plant, Glavcentrostroy did not produce products of the highest quality category. The issues of improving quality were poorly dealt with by the city and district party committees and many primary party organizations.

Defects caused great losses. They amounted to 2.296 thousand rubles for six months, 1.660 thousand of them were made by the Karaganda metallurgical plant, 268 thousand of them were made by the rubber products plant. Unproductive expenses for that period had amounted to 540 thousand rubles, 40 thousand of them were made by Karaganda ugol association [2].

Then the speaker proceeded to the definition of the tasks for 1978: an analysis of the implementation of national economic plans and the commitments made for 1977 indicated that many enterprises and organizations had huge production reserves. That fact had been laid in the foundation for the socialist obligations of the leading labor collectives of the region for 1978. In his extremely vivid, argumentative on the content, conclusions and provisions speech at the December (1977) Plenum of the CPSU Central Committee, Comrade L.I. Brezhnev, Secretary General of the Presidium of the Supreme Soviet of the USSR, had said: «To work today is better than it was yesterday, to work tomorrow will be better than it is today». That was the slogan of those days. And «better» meant an emphasis on quality, on efficiency, on the growth of labor productivity. «It is here that the core of socialist obligations, as well as of all our economic activity are accumulated.»

At the end of the previous year, work meetings had been held in all labor collectives of the region; at them results had been summarized, reserves had been opened, tasks for 1978 had been defined. In an environment of high consciousness, socialist commitments had been made. They had been made by workers, engineers, technicians, brigades, collectives of plots, workshops, departments, farms, enterprises, organizations. The boundaries had been determined for all branches of agriculture, districts and cities of the region [2].

After that N.A. Nazarbayev spoke about the main provisions of the obligations, their characteristic features and emphasized that the main thing was to convey the demands of the day to every communist, every worker, to determine the tasks and exact time frames of their implementation; to skillfully and clearly organize 
work; to create favorable conditions for tasks implementation; all the work had to be based on all-round acceleration of labor productivity growth. Basically the entire increase in the volume of industrial output in the region was planned to be obtained only due to the growth of labor productivity.

It was to be ensured that various measures for the widespread introduction of advanced equipment and technology were to be developed and implemented at every enterprise and construction site. Measures had to be taken to replace, on a large scale, manual labor by machines, especially in auxiliary, loading, unloading, repair and storage operations, as well as to eliminate large unproductive losses of time, and to persistently introduce a new, advanced technologies[2].

In his report N.A. Nazarbayev also spoke about saving metals and other types of products, raw materials, electricity and fuel, more efficient use of production capacities, reducing equipment downtime. N.A. Nazarbayev urged to radically improve the use of fixed assets, increase the capital-labor ratio, energy availability, to achieve rigorous fulfillment of tasks on the growth of labor productivity, and on this basis, to ensure an increase in output.

From the first days of the year, it was very important to support and widely disseminate patriotic undertakings born in advanced collectives. The collective of the Order of Lenin of the Kostenko mine in response to the appeal of Moscow dwellers «to complete the task of three years by the first anniversary of the new Constitution of the USSR» had undertaken to ensure rhythmic, high-performance work and to extract at least 600 thousand tons of coal from the main active lavas per year, and, in addition to the plan, to issue 100 thousand tons of fuel, 40 thousand tons of coal concentrate, and to pass 300 linear meters of mine workings.

In their commitments made for 1978, the leading collectives of mining sites No. 1 and No. 3 of the Mikhailovskaya mine, No. 2 and No. 7 of the mine named after the 50th anniversary of the October Revolution, No. 1 of the Severnaya mine, led by comrades Salamatin, Beisenov, Yesenbayev, Povalyayev, Romanyuta, and tunnel teams led by comrades Kurnikov and Kubaychuk from the Severnaya and Maikudukskaya mines envisaged to produce $500-650$ thousand tons of coal and to pass at least 5000-555 running meters of mine workings. The bureau of the regional party committee had already approved that initiative.

The regional committee's bureau had also approved the initiation of the brigade of V.N. Portyanko from the Karagandazhilstroy trust to master a million rubles in a year's housing construction in good quality, to fulfill the three years of the five-year plan by April 25, the opening of the 18th Komsomol congress, and to fulfill the four years of the five-year plan by October 7, the anniversary of the new Constitution of the USSR; the initiation of the brigade of I.P. Gress from the Karagandaselstroy-10 trust to master at least 830 thousand rubles in a year, to hand over the objects from the first presentation and to fulfill the plan of three years of the five-year plan by the anniversary of the Constitution of the USSR.

Attention and support was deserved by the initiative of a number of Karaganda collectives, following the example of Leningrad dwellers to work out two days, on the day of the Leninist communist subbotnik and in honor of the first anniversary of the new Soviet Constitution, on the saved raw materials.

The struggle for the plan had to be a constant concern of economic leaders, party, trade union and Komsomol organizations. They had to use all organizational forms, all means of ideological and political influence. In order to clarify obligations, bring tasks to each worker, it was important to effectively use the media, timely and deeply reveal best practices, and persistently seek their widespread implementation. It was necessary to increase the role in the oral political and visual agitation. The whole of the ideological asset had to actively join the struggle for a plan, for the fate of obligations.

N.A. Nazarbayev's speech was concluded with the words that time did not stand still. It was January 10th on the calendar. The Central Committee of the CPSU had expressed firm conviction that workers, collective farmers, specialists, and workers in all sectors of the national economy of the Motherland would make 1978 the year of hard work. The best answer to that call of the party would be the early fulfillment of the elevated socialist obligations by each labor collective, the region as a whole [2].

Thus, the published of the 1970s provide an opportunity to reconstruct the activities of N.A. Nazarbayev as the second secretary of the regional committee of the Communist Party of Kazakhstan in the Karaganda region in the period of 1977-1979. Here, N.A. Nazarbayev demonstrated all the great opportunities and hidden potential in managing people and the ability to solve vital issues, noticeably strengthened the regional committee of the party, significantly expanded his sphere of influence. His energy, knowledge, experience, business qualities and great abilities began to manifest even brighter. 
References

1 Индустриальная Караганда. - 1977. - 28 дек.

2 Индустриальная Караганда. - 1978. - 12 янв.

\title{
Г.Т. Едгина, Р.М. Жұмашев, Х. Абу Таам, Л.И. Зуева \\ Н.Ә. Назарбаев - 1977-1979 жж. Қазақстан Компартиясы облыстық партия комитетінің екінші хатшысы
}

\begin{abstract}
1977 жылы желтоқсанда Қазақстан Компартиясы Қарағанды облыстық комитетінің сегізінші пленумында Н.Ә. Назарбаев Қазақстан Компартиясы облыстық комитетінің екінші хатшысы болып сайланды. Жаңа қызметінде Н.Ә. Назарбаев бұрынғысынша, бірақ үлкен көлемдегі міндеттерге кезікті. Қазақстан Компартиясы облыстық комитетінің екінші хатшысы Н.Ә. Назарбаевтың баяндамасын талдау авторлардың мынадай тұжырымдама жасауына мүмкіндік берді. 1977-1979 ж. Н.Ә. Назарбаев адамдарды басқаруда және аса маңызды мәселелерді шешу барысында зор мүмкіндіктерін көрсете білді. Айтарлықтай, партияның облыстық комитетін күшейтті, нығайтты, өзінің ықпалын арттырды. Оның күш-куаты, білімі, тәжірибесі, іскерлік қасиеттері мен зор қабілеті айқын көрінді.
\end{abstract}

Кілт сөздер: Қазақстан Республикасы, Тұңғыш Президент, тарих, хатшы, еңбек қызметі, Қазақстан Коммунистік партиясы, Қарағанды облысы.

\author{
Г.Т. Едгина, Р.М. Жумашев, Х. Абу Таам, Л.И. Зуева
}

\section{Н.А. Назарбаев — второй секретарь обкома Компартии Казахстана в 1977-1979 гг.}

В декабре 1977 г. на VIII Пленуме Карагандинского обкома Компартии Казахстана Н.А. Назарбаев был избрал вторым секретарем обкома Компартии Казахстана. На новой должности Н.А. Назарбаев столкнулся с теми же задачами, как и прежде, но гораздо в большем масштабе. Анализ доклада второго секретаря обкома Компартии Казахстана Н.А. Назарбаева позволил авторам прийти к выводу, что в период 1977-1979 гг. Н.А. Назарбаев продемонстрировал все большие возможности и скрытый потенциал в управлении людьми и умении решать жизненно важные вопросы, заметно укрепил и усилил областной комитет партии, значительно расширил сферу своего влияния. Ещё ярче стали проявляться его энергия, знания, опыт, деловые качества и большие способности.

Ключевые слова: Республика Казахстан, Первый Президент, история, секретарь, трудовая деятельность, Коммунистическая партия Казахстана, Карагандинская область.

\section{References}

1 Industrialnaia Karahanda [Industrial Karaganda] (1977). December, 28 [in Russian].

2 Industrialnaia Karahanda [Industrial Karaganda] (1978). January, 12 [in Russian]. 